\title{
Erkek Dergilerini Anlamak: GQ Türkiye Örneğinde Bir Alımlama Çözümlemesi
}

\author{
Understanding Men's Magazines: An Reception Analysis \\ in The Case of GQ Turkey
}

İlker ERDOĞAN, Erciyes Üniversitesi, Türkiye, ilkgazeteci@gmail.com

\begin{abstract}
Öz: Erkek dergileri ile ilgili okur araştırmalarl, okurların dergi okuma pratiği hakkinda önemli bulgular sağlamaktadır. Bu çalışma, içerik ve haz diyalektiğine odaklanan dergi metinlerinin özellikleri ve gündelik yaşamda yerleşik bir toplumsal pratik olarak dergi okuma pratiği arasındaki önemli benzerlikleri ve uyumu anlamlandırmayı amaçlamaktadır. Bu amaçla, çalış̧ma, alımlama çözümlemesi için seçilen GQ Türkiye dergisinin Ağustos 2013 saylsinda yer alan metinleri ve okurların alımlamalarını çözümlemektedir. Metin çözümlemesi ve alımlama çözümlemesini birleştiren bir metodolojik yaklaşımın benimsendiği bu çalışmada, dergi metinleri ile dergi okuma pratiği arasındaki ilişki incelenmektedir. Dergi metinleri, okur-odaklı metin çözümlemesi yöntemiyle, okur alımlamaları ise, dergi okurlarıyla gerçekleştirilen anket çalışması ve derinlemesine görü̧smelerle çözümlenmiştir. Sonuç olarak, $G Q$ Türkiye dergisinin metinsel özellikleri ile okurların alımlamaları arasında benzerlikler olduğu görülmüsstür. Bu benzerliklerin nedeni hem GQ Türkiye dergisindeki içeriklerin popüler bir nitelikte olması hem de okurların gündelik yaşam pratiklerinin popüler tarzda oluşturulan içeriklerle örtüşüyor olmasıdır.
\end{abstract}

Anahtar Kelimeler: Erkek dergileri, GQ, Türkiye, metin, okur, alımlama

\begin{abstract}
Reader research on men's magazines has provided significant findings about magazine reading practice of readers. This study aims to make sense of important similarities and harmony between features of magazine texts focusing on the dialectic of content and pleasure, and magazine reading practice as a social practice situated in everyday life. To this end, it analyzes texts in August 2013 of GQ Turkey magazine that is selected for reception analysis, and receptions of readers. It's examined the relationship between magazine texts and magazine reading practice in this study which is adopted a methodological approach which combines textual analysis and reception analysis. Magazine texts are analyzed through reader-guided textual analysis method, reader receptions are analyzed through a questionnaire survey and in-depth interviews with magazine readers. Finally, there are similarities between textual features of GQ Turkey magazine and receptions of readers. Those similarities are based on popularity of contents in GQ Turkey magazine, also everyday life practices of readers correspond to popular contents.
\end{abstract}

Keywords: Men's magazines, GQ, Turkey, text, reader, reception

\section{Giriş}

Gündelik yaşamın bir parçası haline gelen ve insanların mağazalarda ya da gazete bayilerinde görmeye alışık olduğu erkek dergileri, popüler kültürü ve tüketimi özendirmenin yeni bir biçimidir (Benwell, 2003a, 8; Gauntlett, 2008, 164). $\mathrm{Bu}$ çalşşada, özellikle içerik ve haz diyalektiğine odaklanan dergi metinlerinin özellikleri ve gündelik yaşamda yerleşik bir toplumsal pratik olarak erkek dergilerini okuma pratiği arasındaki olası ilişki irdelenmektedir. Söz konusu ilişki, anket, derinlemesine görüşme ve okur-odaklı metin çözümleme yöntemleri aracılığıyla çözümlenmektedir. Erkek dergileri odaklı okur araştırmaları, dergi metinleri ve okurların dergi okuma pratiği hakkında dikkate değer bulgular içermektedir (Jackson vd., 1999, 2001; Benwell, 2005). Nitekim bu çalışma, GQ (Gentlemen's Quarterly) Türkiye dergisinin metinsel özellikleri ve söz konusu dergiyi okuma pratiği arasındaki olası benzerlikleri ve uyumu anlamlandırma çabasının bir ürünüdür.

Dergileri örneklem olarak kabul eden akademik çalışmaların pek çoğu, içerik, ideoloji ve okur merkezlidir. Ayrıca, tür olarak dergileri ele alan akademik çalışmaların büyük bir çoğunluğu, kadın dergilerinde, kadın kimliğini nitelendiren çalışmalardır (Benwell, 2004, 7). Ne var ki erkek dergileri odağında yapılan çalı̧̧malar, feminist çalışmalar eksenindeki kadın dergileri ile kıyaslandığında çok daha sınırlıdır (Stevenson, 2002, 110). Ayrıca, alanyazına alımlama çözümlemeleri etrafında bakıldı̆̆ında kadın (Frazer, 1987; Hermes, 1995; Currie, 1999; Ytre-Arne, 2011a, 2011b, 2011c) ya da erkek (Jackson vd., 1999, 2001; Benwell, 2005) dergileri ile ilgili çalışmaların görece daha az olduğu 
görülmektedir. Söz konusu alanyazın, Türkiye'de erkek dergilerini inceleyen az sayıda çalışmanın (Batı, 2007; Aydoğan, 2008; Kula Demir, 2009; Erdoğan, 2011, 2013a, 2013b, 2014) yalnızca medya, içerik ve popüler kültür metni odağında yapıldığını göstermektedir. Ne var ki yapılan çalışmalar, dergi okurlarının gündelik yaşamda yerleşik bir toplumsal pratik olarak erkek dergilerini okuma deneyimine odaklanmamıştır. Dolayısıyla, özellikle okur tarafından erkek dergilerinin popüler bir medya ve içerik türü olarak nasıl kullanıldığı (bu dergilerin tüketilme biçimi ya da bu dergilerden faydalanma biçimi), yorumlandığ 1 ve deneyimlendiği, bu çalışma aracılığıyla ortaya konulacaktır.

Çalışma iki temel varsayıma dayanmaktadır. İlki, okur ile araştırmacıların popüler bir metin olarak erkek dergilerini okuma biçimleri arasında potansiyel farklılıklar olduğudur. Bu noktada, erkek dergileri hakkında yapılan çalışmalarda, okur ile araştırmacıların ciddi yorumlama ve anlamlandırma farklılıkları olabileceği öngörülmelidir. İkinci varsayım ise, alımlama çözümlemesi ile metin çözümlemesini birleştiren metodolojik bir yaklaşımın kaçınılmazlığıdır. Nitekim erkek dergilerinin neden ve nasıl okunduğunu anlama çabası, metinsel özellikler bağlamında ilgili deneyimin ayrıntılı biçimde çözümlenmesini gerektirmektedir. Bu çalışma, hem sıradan bir okur olduğunu hem de sürekli dergi okumadığını iddia eden okurları kapsamaktadır. Öncelikle okurların erkek dergilerini yorumlama ve deneyimleme süreci sorgulanmakta; GQ Türkiye dergisinin metinsel özellikleri ile okurların okuma pratiği arasındaki olası ilişki çözümlenmektedir.

Bu noktada, popüler kültür ya da kitle kültürü alanındaki izlerkitle araştırmalarının bazı zayıf yönlerinin ya da eksikliklerinin olduğunu belirtmek gerekmektedir. Bu tür araştırmalarda, içerik ve alımlama arasındaki sistematik ilişki açıklanmaya çalışılsa da indirgemeci bir bakış açısı sergilenmekte ve metin ihmal edilmektedir. İkinci önemli nokta ise, bu araştırmalar aracılığıyla toplanan etnografik bulgularda herhangi bir problem görülmemesidir (Benwell, 2005, 150). $\mathrm{Bu}$ çalışmada, veri çeşitlemesi yapılarak anket ve derinlemesine görüşme yöntemi ile okur odaklı metin çözümleme yöntemi bir arada kullanılmış; dergi metinleri ile okuma pratiği arasındaki etkileşime odaklı metodolojik bir yaklaşım benimsenmiştir. Özellikle metin çözümleme yöntemi, araştırmacının ilgi ya da öngörüsünden ziyade dergi okurlarının deneyimleri açısından önem arz eden konular etrafında yapılmıştır.

Bu bağlamda, çalışmada, üç önemli araştırma sorusuna yanıt aranmıştır: (1) GQ Türkiye dergisi okurlarının bu dergiden beklentileri nelerdir? (2) GQ Türkiye dergisinin metinsel özellikleri ile okurların okuma deneyimi arasında benzerlik ve uyum var mıdır? (3) Derginin içeriği ve okurların gündelik yaşam pratikleri, söz konusu benzerliklerin ve uyumun kaynağı olarak kabul edilebilir mi? Bu sorular etrafinda, GQ Türkiye dergisine abone olan okurlara uygulanan anket ve derinlemesine görüşmelerden elde edilen veriler çözümlenmiş ve bulgular yorumlanmıştır. Okur alımlamalarının çözümlenmesi ile erkek dergilerinin okunma, kullanılma, yorumlanma ve deneyimlenme biçimlerinde çokanlamlılık ve ikilemler ortaya çıkmıştır. Bu çokanlamlılıklara, dergi metinlerinin çözümlenmesi için yararlı birer başlangıç noktası olarak başvurulmuş ve metin çözümlemesi ile önemli anlamlar üretilmiştir. Farklı yaş gruplarından olduğu saptanan katılımcılar, dergiyi okuduklarını ve dergiyi kendi yaşamları için uygun, kullanışlı ve faydalı bulduklarını ifade etmişlerdir.

\section{Erkek Dergilerinin İçeriği ve Okurları}

Erkek dergilerinin içeriği temel birtakım özelliklere sahiptir. Bu özellikler, erkek dergilerinin hem diğer popüler medya ve içerik türlerine benzemesine hem de bu türlerden farklılaşmasına neden olmaktadır. Erkek dergileri içerik açısından değerlendirildiğinde, en göze çarpan özelliklerden biri, erkek okurlara; kız arkadaşları ve eşleri ile ilişkileri, duygusal ikilemleri, sağlık ve formda olma, vücut bakımı ve erkek modası hakkında önerilerde bulunmasıdır (Gregorio Godeo, 2006a, 44-45; 2006b, 89). "Eğitici bir üslup" kullanan "eğitici bir tür" olarak erkek dergileri, sayfalarında tavsiye sütunlarına yer vermektedir (Schirato ve Yell, 1999, 84). Erkek okurların, erkeğe özgü yaşam biçimi ile ilgili soru sorabildiği bu sayfalarda, erkeklerin gönderdikleri mektuplara odaklanılmakta ve bu mektuplara cevap niteliğinde (okurların bu sorunlarla baş edebilmesi için ne yapması gerektiğine dair) önerilerde bulunulmaktadır. Okurlar tarafından gönderilen sorularda, kendi sorunları hakkında yardım arayışı içinde olan erkeklerin, sorunlarına ilişkin tutumları (Spalding vd., 2010) dikkat çekmektedir. Bu dergilerin, erkek okurların yardım arayışına verdikleri cevaplarda ise, dergilerin, bu arayışa, erkekliği geleneksel olarak tanımlayarak, tanımlamaları sürdürerek, yineleyerek ya da destekleyerek karşıllk verdikleri (Stevenson vd., 2000) görülebilmektedir. Örneğin, Anstiss ve Lyons (2013), Men's Health ve FHM (For Him Magazine) dergilerinin tavsiye sütunlarında yer alan okur mektuplarını ve uzman yanıtlarını söylemsel olarak çözümledikleri çalışmalarında, okur mektuplarında, kendine güvenen, bağımsız, bilgili, sabırlı ve kadınsılık ile ilişkilendirilmekten kaçınan bireyler olarak konumlanan erkeklerin, uzmanların yanıtlarında olumlu bir şekilde pekiştirildiğini belirlemiştir. Ayrıca, diğer erkek tiplerine, alaycı bir şekilde cevap verildiğini ve dolayısıyla da, dergi metinlerinin, kabul edilebilir ya da kabul edilemez erkeklik temsillerinin sınırlarını belirleyerek hegemonik idealleri pekiştirdiğini ortaya koymuştur.

Erkek dergilerindeki içeriğin bir diğer özelliği, içeriğin genellikle tüketime özendiren yaşam biçimlerini teşvik etmesi, modern erkeklikleri ortaya çıkarması ve özellikle de yeni erkek gibi (yeni) erkeklik biçimlerini inşa etmesidir (Attwood, 2005, 84). Aslında, aşırı tüketime ve göz alıcı hale getirilen yeniden üretime odaklanan erkek dergileri, erkeklerin ilişkilerine, iş yaşamına ve yaşam tercihlerine dair önerilerde bulunmakla birlikte, okurlarını, genellikle satın almaları, giyinmeleri ve yemeleri gereken ürünlere yönlendirmektedir (Hollow, 2012, 17). Stevenson ve diğerlerinin $(2003,129)$ ifade ettiği gibi, erkek dergileri, "yeni pazarları teşvik eden ve değişen modern erkekliğin tanımını yapan 
kapitalizmin başarısı ile ilgili olarak kültürel iktidar kaynakları"dır. Bu nedenle, erkek dergilerini incelerken göz önünde bulundurulması gereken bağlam kuşkusuz tüketim toplumudur (Jackson vd., 2001). Erkek dergileri öncelikle, sayfalarında yeni erkek(lik) modellerini ya da biçimlerini simgeleyen ünlü erkek ikonlarla ve şöhretlerle yapılan röportajlara yer vermektedir. Erkek dergilerinde, ünlü erkek ikonlarla ve şöhretlerle yapılan röportajların yanı sıra, sağlık, spor ve formda olma, cinsel ilişki ve kadınlar, seyahat, sanat ve erkek modası ile ilgili konulara da yer verilmektedir. Erkek giyimi, aksesuarlar, tütün, alkol ve teknoloji ile ilgili reklamlar ön plana çıkarılmaktadır. Ayrıca, erkek dergilerinde sunulan en yaygın temalar, kadınlara bakmaktan hoşlanan erkekler, kadınlar hakkında çok fazla şey bilmeyen erkekler, otomobillerden ve spordan hoşlanan erkekler, yardıma ihtiyaç duyan erkekler ve aynı zamanda, cesur ve tehlikenin cazibesine kapılmış erkeklerdir (Gauntlett, 2008, 171-173).

Erkek dergilerinin içeriğinde görülen en önemli özelliklerinden bir diğeri de, kolay anlaşılır bir tür olarak erkek dergilerinin içeriğinin değişkenliğidir. Erkek dergileri, ön kapaklarında idealleştirilen erkek beden imajını sunarak kadın okurları kendisine çekmeye çalışmaktadır. Bazen de, ön kapaklarına, yeni erkek imajına eşlik ettiği hissi uyandıran homo-erotizme karşı çıkarak ve erkek-yaşam biçimi dergilerinin alternatifi olan bir tür olarak yumuşak-pornografik dergileri taklit etmeye çalışarak, idealleştirilen erkek beden imajının yerine cinselleştirilen kadın bedeni imajını yerleştirmektedir (Benwell, 2002, 158). Ayrıca hem erkek hem de kadın dergilerinin kapaklarında yer alan görsel imajların; kadınların, benzemeleri gereken şeyi, erkeklerin ise, aramaları ya da bulmaya çalışmaları gereken şeyi tasvir etme eğiliminde olduğu öne sürülmektedir (Malkin vd., 1999, 652). Aslında, dergiler için bir kurala dönüşmüş olan bu yaklaşımın erkek dergileri tarafından benimsendiği de görülmektedir. Örneğin, Men's Health dergisi, heteroseksüel erkeklerin; bağrı açık, kaslı ve bakımlı erkeklerin görsel imajlarını sunan bir erkek dergisini satın alacağını varsaymakta ya da bu yaklaşımın doğru olduğunu kanıtlamaktadır.

Erkek dergilerinin ideal okurları, genç, çalışan sınıfa mensup, düşük statüye sahip, mesleki güç eksikliğini telafi etmek için bu dergilerde tasvir edilen güçlü bedenlere sahip olmak isteyen (aktaran Vigorito ve Curry, 1998, 138), aynı zamanda, kendine özgü ve çoğunlukla bekar, zengin, şehirli, kazancı yüksek ve çok para kazanıp çok para harcayan heteroseksüel erkeklerdir. Diğer erkekler ise, bu yaşam biçimini ya da onun değerlerini benimsememektedir (Edwards, 1997, 76). Ayrıca, erkek dergilerinin okurları, narsist (kendine aşık) erkeklerdir. Bununla birlikte, erkek dergileri, narsist erkek okurların bakışlarının, farklı ürünlerin reklamını yapmak için kullanılan çok sayıda ve yarı çıplak erkek imajına yöneldiğinin farkında olmakla birlikte, homoseksüelliği reddetmekte ve geleneksel toplumsal cinsiyet farklılığını desteklemektedir. Bütün bunların ötesinde, samimi ve kişilerarası bir üsluba sahip olan (Benwell, 2003b) ve cana yakın bir şekilde, okurlarıyla alay etmeden, onlara yol gösteren (Rogers, 2005, 180) erkek dergileri, okurları ile arkadaş olmak istemektedir (Stibbe, 2004, 36). Homoseksüellikle ilişkilendirilmekten kaçındığı için erkek-yaşam biçimi dergilerinin, okurlarına, arkadaşları gibi davrandığı ve kadın bedenleri ile heteroseksüel cinsiyeti ya da cinsel ilișkiyi önemle vurguladığı varsayılmaktadır (Gill, 2003). Oysa erkekler, "kendi cinsiyeti hakkında öz-bilince sahip değildir". Erkeklerin, bir erkek olmaktan, erkek modasından ve erkeklerin sorunlarından bahsedilen bir dergiyi satın almak isteyip istemeyeceğine dair bir belirsizlik de söz konusudur (Gill, 2003, 43).

\section{Erkek Dergileri Bağlamında Okur Araştırmaları}

Jackson ve diğerleri $(1999,2001)$ tarafından erkek dergileri ile ilgili olarak gerçekleştirilen okur araştırmalarında, erkek dergilerinin içeriği, özellikle de, okurlara sunulan söylemler ya da fanteziler incelenmiş ve aynı zamanda, editörlerle ve dergilerin okurları olan genç erkeklerle görüşmeler yapılmıştır. Dergilerin içeriği incelendiğinde, erkek dergilerinin, okurlara, sorunlarıyla baş edebilmeleri için ne yapmaları gerektiğine dair önerilerde bulunduğu, bu önerilerin ironik bir dille ifade edildiği ve bu dergilerin, okurları ile arkadaş olmaya çalıştığı görülmüştür. Ayrıca, Jackson ve diğerleri (1999), erkek dergileri hakkında erkeklerle gerçekleştirdikleri derinlemesine görüşmelerde, erkeklerin, feminizmin topluma yerleştirmiş olduğu değişimlerle daha uyumlu bir kişisel görüşü ifade etmenin diğer biçimlerinin eksikliği nedeniyle, geleneksel ve cinsiyetçi yorumlama kaynaklarına başvurma eğiliminde oldukları sonucuna ulaşmıştır. Bununla birlikte, Jackson ve diğerleri (1999), pek çok okurun, hatta dergileri düzenli olarak satın alan, dergilere bağlı okurların bile, dergileri, yüzeysel ve tek kullanımlık ürünler olarak değerlendirdiklerini belirlemiştir. Okurların ön kapaktan arka kapağa kadar dergiyi okumaktan ziyade, yalnızca dergilere göz atmak ya da dergileri gözden geçirmek istediklerini ortaya koymuştur. Ayrıca, erkek dergilerinin, düşük nitelikte, gereksiz bir harcamaya neden olan, anlamsız, saçma ve yüzeysel araçlar, bir başka ifadeyle, değersiz ya da önemsiz kültür ya da fikir araçları olduğuna dair bir yaklaşımın da var olduğu ortaya konulmuştur (Jackson vd., 1999, 358). Ancak, okurların, erkek dergilerini, kullanmak amacıyla satın almaları ve yalnızca sıradan bir okur olduğunu ya da sürekli dergi okumadığını iddia eden bir erkeğin, yatağının yanında bir derginin eski sayılarını saklaması (bu, Jackson ve diğerlerine ait -1999- bir gözlemdir) bu yaklaşımın kabul edilmesini mümkün kılmamaktadır.

İzler kitle araştırmalarının, erkek dergilerindeki söylemlerin kültürel anlamlarını anlamlandırma fırsatı sunduğunu belirten Benwell (2005) ise, alımlamanın, çoğunlukla farklı, özerk ve tarih dışı metinler olarak ele alınan popüler kültür metinlerinin dilbilimsel çözümlemelerinde sıklıkla ihmal edilen bir kültürel alan olduğunu öne sürmektedir. Ona göre, dergi okurları ile gerçekleştirilen yapılandırılmamış derinlemesine görüşme tekniği, pek çok etnografik yaklaşımın aksine, alımlamanın bağlamlarını ilişkilendirmenin bir aracıdır. Derinlemesine görüşme, alımlamanın anlaşılır bir raporundan ziyade, tartışmasız yerleşik bir açıklamasıdır. Bununla birlikte, Benwell (2005), derinlemesine 
görüşmelerdeki bağlamın terimlerini açıklamak için dergi metni, medya tartışmaları, editöryal benzerlikler ve gündelik görüşme gibi kültür dolaşımındaki diğer iletişimsel bağlamlar ile görüşmede tanımlanan söylemlerin ve kategorilerin metinlerarası bir şekilde ilişkilendirilebildiği bir yöntem önermektedir.

\section{Yöntem(ler)}

Alasuutari’ye (1999) göre, izlerkitle araştırmaları, alımlama, izlerkitle etnografyası ve yorumlayıcı bir bakış olmak üzere üç temel araştırma yaklaşımı kapsamında gerçekleştirilmektedir. Alımlama araştırmalarının geçmişi, Stuart Hall'un (1974) Televizyon Söyleminde Kodlama ve Kodaçımlama başlıklı çalışmasına kadar uzanmaktadır. Kodlama ve kodaçımlama modeli, kitle iletişimine, belirli mesajların gönderildiği ve daha sonra belirli anlamların ortaya çıktığı bir süreç olarak yaklaşmaktadır. Hall, çalışmasında (aktaran Alasuutari, 1999, 4), izlerkitle tarafından gerçekleştirilebilen üç farklı okuma pratiğinin söz konusu olduğunu öne sürmektedir. Egemen ya da hegemonik okuma pratiğinde, okurlar, tercih edilen anlamların egemenliği açısından kodaçımlamaktadır. Müzakereli okuma pratiğinde, okurlar, uyarlanabilir ve muhalif unsurlarla kodaçımlamaktadır. Karşıt okuma pratiğinde ise, okurlar hem tam hem de yan anlamları mükemmel bir şekilde anlayarak kodaçımını yapmaktadır. Egemen ya da hegemonik okuma pratiğinde, izlerkitle, yapımcının yeğlediği biçimde hareket etmekte, metindeki düz anlamları tam ve doğru olarak almakta ve kodlama sürecinde üretilen anlamların meșruluğunu her düzeyde kabullenmektedir. Müzakereli okuma pratiğinde, izlerkitle yine egemen tanımların ve anlamların meşruluğunu kabul etmekte, ancak, daha sınırlı bir düzeyde kendi konumuna uygun anlamlar üretmekte ve bu nedenle, sık sık yeğlenen okuma pratiğinin dişına çıkmaktadır. Karşıt okuma pratiğinde ise, izlerkitle, metnin egemen kodlarla doldurulduğunun farkındadır ve bu nedenle, aynı metni kendi alternatif başvuru kodlarıyla yeniden inșa etmektedir. Yani, metindeki kodların meşruluğunu reddetmektedir (Hall, 2005, 96-97). Bu üç farklı okuma pratiğini saha araştırmaları ile irdeleyen David Morley, Nationwide adlı çalışmasında, izlerkitlenin, televizyon programlarının şifresini çözme biçimlerini sınıfsal konumun belirleyeceği varsayımını kanıtlamaya çalışmış ve Nationwide adlı dizi-belgesel programın anlamına ilişkin yorumların toplumsal kümelere göre nasıl farklılaştığını ortaya koymuştur (Mutlu, 2005, 135). David Morley, Family Television adlı çalışmasında ise, televizyon izlemenin, aile içi ilişkilerdeki rolünü ve cinsiyete bağlı program tercihlerini araştırmıştır (İrvan, 1994-95, 209).

İzler kitle etnografyası, ampirik/pozitivist alımlama paradigmasından izlerkitle etnografyası paradigmasına doğru bir değişime ya da dönüşüme işaret etmektedir. Bu değişim ya da dönüşüm kapsamında ortaya çıkan izlerkitle etnografyası araştırmaları da, özellikle, romantik diziler ya da sevda romanları gibi televizyon programlarını ve derinlemesine görüşme yöntemi ile izlerkitlenin alımlamalarını çözümleyen niteliksel izlerkitle araştırmaları olarak bilinmektedir. 1980'li yılların sonunda ise, kültürel izlerkitle araştırmalarının başlangıç noktası olarak, pek çok akademisyen izlerkitle etnografyasının önermelerini sorgulamaya ve tartışmaya başlamış ve yorumlayıcı bir bakış ortaya çıkmıştır. Pek çok akademisyene göre, üretici (yayıncı), metin ve izlerkitle ile birlikte ya da onlara alternatif olarak, insanların gündelik yaşamları da, bir hareket noktası ve araştırma nesnesi haline gelmiştir.

Jensen ve Rosengren'e $(2005,56)$ göre de, izlerkitle araştırmaları, etkiler araştırması, kullanımlar ve doyumlar araştırması, edebi eleştiri, kültürel çalışmalar ve alımlama çözümlemesi olmak üzere beş ana araştırma yaklaşımı kapsamında gerçekleştirilmektedir. İzler kitle araştırmaları alanındaki en yeni gelişme olarak kabul edilen ve kültürel çalışmalar geleneği ile kaynaşan alımlama çözümlemesi hem ampirik izlerkitle araştırmalarının çeşitli biçimlerini kapsamakta hem de alımlama ile ilgili toplumsal-bilimsel ve beşeri perspektifleri birleştirmeye çalışmaktadır (Jensen ve Rosengren, 2005, 62). İçerik ve izlerkitle ilişkisi ile ilgili ampirik bir çözümleme olan alımlama çözümlemesi, derinlemesine görüşme ve gözlem gibi araştırma tekniklerini kullanarak izlerkitle hakkında ampirik bulgular elde etmekte, bu bulguları içeriğe ilişkin bulgularla karşılaştırmakta ve netice itibariyle, alımlama süreçlerini inceleyerek medya içeriğinin kullanımı ve etkileri ile ilgili bir tutum geliştirebilmeyi amaçlamaktadır (Jensen ve Rosengren, 2005, 63). İzler kitleyi oluşturan bireyleri etkin bireyler olarak gören alımlama çözümlemesi, medya söylemleri ile izlerkitle söylemlerini, bir başka ifadeyle, içerik yapıları ile içeriğe ilişkin izlerkitle tepkilerini ampirik ve karşılaştırmalı olarak çözümlemekte ve çözümlemenin sonuçları, sosyo-kültürel sisteme gönderme yapılarak yorumlanmaktadır (Jensen ve Rosengren, 2005, 66).

Alımlama, izlerkitlenin; televizyon programları ile ilgili yorumlarına, kodaçımlamalarına, okuma pratiğine, anlam üretimlerine, algılarına ya da kavrayışlarına işaret eden genel bir terim olarak kullanılabilmektedir. Araştırmacının kullandığı terminoloji, onun akademik geleneğine bağlıdır, ancak, onun bakış açısı ne olursa olsun, alımlama araştırmaları, metin çözümlemeleri ve izlerkitlenin tepkileri arasında bir ilişki kurmak zorundadır (Hoijer, 2005, 105106). Çünkü izlerkitle araştırmalarını nitelendiren iki temel varsayım; izlerkitlenin her zaman etkin ve medya içeriğinin her zaman çok anlamlı ya da yoruma açık olduğudur (aktaran Morley, 2005, 99). Bu nedenlerle, GQ Türkiye dergisinin metinsel özellikleri ile okurların okuma pratiği arasındaki olası benzerlikleri ve uyumu anlamlandırmayı amaçlayan bu araştırmada, metinler ile dergi okurlarının okuma pratiği ayrı ayrı çözümlenmemiştir. Aksine, araştırma kapsamında iki aşamadan oluşan bir alımlama çözümlemesi gerçekleştirilmiştir. Alımlama çözümlemesinin birinci aşamasında, GQ Türkiye dergisinin okurları (aboneleri) arasında gerçekleştirilen bir anket uygulamasından, ikinci aşamasında da, derginin okurları ile yapılan derinlemesine görüşmelerden elde edilen bulgular değerlendirilmiştir. Daha sonra da, okurodaklı bir metin (niteliksel içerik) çözümlemesi gerçekleştirilmiştir. 


\subsection{Dergi Örneklemi}

Bu araştırmada, dergi metinleri ihmal edilmemiştir. Dergi örneklemi, orijinal baskısı, küresel medya grupları tarafından yayımlanan ve uluslararası erkek dergileri pazarında satışa sunulan; içeriği, orijinaline sadık kalınarak yeniden üretilen ve Türkiye'de yayımlanan erkek dergileri arasından seçilmiştir. Ayrıca, bu çalışma, özellikle Türkiye'de, erkek dergilerinin metinsel özelliklerine ve okurların okuma pratiğine odaklanan ya da odaklanacak okur araştırmalarında, etnografik bulgular elde etme noktasında, gündeme gelebilecek beş temel sorunun ya da ikilemin (Bkz. Ek 1) varlığını kabul etmektedir. GQ Türkiye dergisi, bu sorunlar ya da ikilemler dikkate alınarak seçilmiş ve bu derginin okurları ile yapılan anket uygulamasından ve derinlemesine görüşmelerden elde edilen veriler değerlendirilmiştir.

Küresel medya grupları tarafından yayımlanan, uluslararası erkek dergileri pazarında satışa sunulan ve Türkiye'de de popülerliğini artıran erkek-yaşam biçimi dergilerinin (Men's Health, Esquire, GQ Türkiye) yöneticilerine (genel yayın yönetmenlerine) erişebilmek mümkün olmuştur. Ancak, bu dergiler arasında yalnızca GQ Türkiye dergisinin yayın koordinatöründen olumlu yanıt alınabilmiștir ${ }^{1}$. Doğuş Yayın Grubu Dergiler Pazarlama ve Projeler Direktörü, Doğuş Yayın Grubu tarafından gerçekleştirilen ve GQ Türkiye dergisi okurlarının (abonelerinin) içerik tercihlerini saptamak ve okur düşüncelerini derlemek amacıyla, 31 Temmuz-4 Eylül 2013 tarihleri arasında GQ Türkiye okuru 436 kişi ile yapılan anketin ve derinlemesine görüşmelerin bulgularını yazarla paylaşmıştır. Küresel bir medya grubu tarafindan yayımlanan FHM (For Him Magazine), yerli bir medya grubu tarafindan yayımlanan Erkekçe ve yayın hayatına son verilen Boxer gibi dergiler, erkek-yaşam biçimi dergilerinin alternatifi olan yumuşak-pornografik dergilerdir. Bu dergilerin yöneticileri ile herhangi bir görüşme yapılmamıştır. Dolayısıyla, yalnızca GQ Türkiye dergisinin okurları ile bir alımlama çözümlemesi yapabilmek mümkün olmuştur. Ancak, erkek dergileri arasında bir karşılaştırma yapabilmek mümkün olmamıştır. Ayrıca, kategorik bir genelleme yapabilme olasılığı da ortadan kalkmıștır.

Bu çalışmada çözümlenen GQ dergisi; yemek, sinema, formda olma, cinsel ilişki, müzik, seyahat, spor ve teknoloji konuları ile ilgilenen ve özellikle tematik olarak modaya, stile ve kültüre odaklanan popüler bir erkek-yaşam biçimi dergisidir. Türkiye'de ilk sayısı Mart 2012'de yayımlanan GQ dergisi, Amerika Birleşik Devletleri'nde 1931 yılında, Apparel Arts (giyim kuşam sanatları) için bir erkek (stil-moda) dergisi olarak yayımlanmaya başlamıştır (Osgerby, 2001, 42). 1988 yılında da, Büyük Britanya'da, pahalıya mal olan şık bir yaşama ve modaya odaklanan bir erkek dergisi olarak piyasaya sürülmüştür (Gregorio Godeo, 2006a, 44). GQ dergisi, tüm dünyada, Avustralya, Brezilya, Çin, Fransa, Almanya, Hindistan, İtalya, Japonya, Meksika, Portekiz, Romanya, Rusya, Güney Afrika, Güney Kore, İspanya, Türkiye, Büyük Britanya ve Amerika Birleşik Devletleri gibi farklı lokasyonlarda yayın hayatını sürdürmektedir.

\subsection{Katllımcllar ve Veri Toplama Tekniği}

Alımlama araştırmalarında, nitel-derinlemesine görüşmeleri yürütmek ve çözümlemek çok uzun zaman almaktadır. Bu nedenle, çok sayıda katılımcı ile gerçekleştirilen derinlemesine görüşmeler kullanışlı değildir (Hoijer, 2005, 127). Ayrıca, alımlama araştırmalarında, nitel yöntemler kullanıldığı için görüşme örnekleminin istatistiksel olarak çok fazla temsil edici olmadığı ve bu nedenle bulguların genelleştirilemeyeceği de bir ön kabuldür (Jensen, 2005, 136). Bununla birlikte, erkek dergileri, hedef okur kitlesini erkeklerin oluşturduğunu varsaymaktadır, ancak, erkek dergilerinin hedef okur kitlesini sadece erkekler oluşturmamaktadır ve bu nedenle, erkekler tarafından okunan ya da okunduğu varsayılan erkek dergilerinin, kadınlar tarafindan okunması olasıdır. Bununla birlikte, erkek dergilerine abone olan okur kitlenin büyük çoğunluğunu erkekler oluşturmaktadır. Bu nedenle, 31 Temmuz-4 Eylül 2013 tarihleri arasında GQ Türkiye okuru 436 kişi ile yapılan anketin ve derinlemesine görüşmelerin soruları, yalnızca erkekler tarafından değil, kadınlar tarafından da cevaplanmıştır. Katılımcılar, GQ Türkiye dergisini yayımlayan medya grubu tarafindan online olarak bir araya getirilmiştir. Yayın grubu, katılımcılara erişerek, katılımcılardan anket ve derinlemesine görüşme sorularını cevaplamalarını istemiştir. Anket ve derinlemesine görüşme soruları, toplam 436 katılımcı (abone) ile paylaşılmış ve katılımcıların tamamı anket ve derinlemesine görüşme sorularına cevap vermiş̧ir. Yaşları 15 ile 54 arasında değişen katılımcılar arasında en geniş katılımcı kategorisini ortalama 25-34 yaş grubu (\% 46) oluş̧urmuş̧ur. Katılımcıların, genel olarak \% 93'ü erkek, \% 7'si kadın, \% 75'i bekar, \% 23'ü evli, \% 2'si boşanmış ya da dul, \% 84'ü büyük şehirlerde yaşayan ve \% 73'ü 20-34 yaş grubundaki okurlardır. Ayrıca, okurların tamamı dergiye abone olmakla birlikte, \% 69'unun her ay, \% 23'ünün 2-3 ayda bir, \% 3'ünün 4-5 ayda bir, \% 3'ünün yılda bir iki defa ve \% 2'sinin de dergiyi daha seyrek okudukları belirlenmiştir.

Anket uygulaması, iki temel amaçla gerçekleştirilmiştir. Birincisi, tematik çözümleme için farklı materyaller üretilmek istenmiş ve bu nedenle de, anket ve derinlemesine görüşme formunda (Bkz. Ek 2), önceden tanımlanmış alternatifli sorulara yer verilmiştir. Derinlemesine görüşmelerde, katılımcılardan, erkek dergilerini okuma alışkanlığını ya da okuma pratiğini kendi sözcükleri ile tanımlamaları istenmiştir. Ayrıca, anket sorularına verilen her cevap, ayrı bir birim olarak çözümlenmiştir. Anket formunu dolduran katılımcılardan, araştırmanın ikinci aşaması olan derinlemesine görüşmelere de katılmaları istenmiş̧tir ve anket sorularına cevap veren tüm katılımcılar bu daveti kabul etmiş̧tir.

\footnotetext{
${ }^{1} \mathrm{Bu}$ çalışmadaki katkıları nedeniyle, $G Q$ Türkiye dergisi yayın koordinatörü Seda Ercan’a ve Doğuş Yayın Grubu Dergiler Pazarlama ve Projeler Direktörü Ahu Terzi’ye çok teşekkür ederim.
} 
Derinlemesine görüşmeler için yapılandırılmış derinlemesine görüşme protokolünde ya da formunda (Bkz. Ek 2), açık uçlu iki soruya yer verilmiştir. Her görüşme hemen hemen aynı konuları içerirken, her konuya ayrılan zaman miktarı, her katılımcının söylemek zorunda olduğu şeye göre önemli ölçüde farklılaşmamıştır. Görüşmelerde verilen cevaplar tematik olarak çözümlenmiştir. Örneğin, derinlemesine görüşmelere katılan katılımcılardan ankette ortaya koymuş oldukları cevapları detaylandırmaları istenirken, bu analitik temalardan biri, katılımcıların erkek dergilerini okunduklarında içinde bulundukları gündelik koşullar ya da durumlar olmuştur. Ankete katılan 436 katılımcının vermiş olduğu cevaplar, dergi okuma pratiğine ya da pratiklerine ilişkin birtakım kısa tanımlamaların yapılmasını sağlamış ve 436 derinlemesine görüşmenin not dökümü, daha az, ancak, çok daha detaylı ve küçük farklara sahip açıklamaların yapılmasını mümkün hale getirmiştir. Materyaller, zengin ve ilgi çekicidir, ancak, araştırma, katılımcılar tarafından deneyimlendiği şekliyle erkek dergilerinin yapısı ve içeriği hakkında birtakım soruları da beraberinde getirmiştir.

\section{Bulgular}

$\mathrm{Bu}$ araştırmada, GQ Türkiye dergisinin metinsel özellikleri ile okurların okuma pratiği arasındaki benzerlikleri ve uyumu anlamlandırmak amacıyla Ytre-Arne (2011a) tarafından ortaya konulan araştırma birimleri dikkate alınmıştır. GQ Türkiye dergisinin metinsel özellikleri, yinelenen metin yapıları ile yinelenen metin temaları; okurların okuma pratiği ise, bir medya türü olarak dergi ve okuma pratiği ile bir içerik türü olarak dergi ve okuma pratiği olmak üzere iki genel alt başlık kapsamında çözümlenmiştir.

\subsection{Dergi Okurlarının Okuma Pratiği}

Bu araştırmadaki anket çalışması ve derinlemesine görüşmeler, özellikle şu noktalara yoğunlaşmıştır: Erkek ya da kadın okurların, dergi okuma pratiğini gerçekleştirdikleri koşullara ya da dergi okuma pratiğindeki ayrıntılara ve dergi okuma tercihleri ile dergi içeriğinin yorumlanma ya da anlamlandırılma biçimlerine odaklanmıştır. Bu koşullar ya da ayrıntılar, tercihler ve yorumlanma ya da anlamlandırılma biçimleri arasında bir ilişki kurmaya çalışmıştır. Ancak, çalışmada, araştırmacı, bir medya türü olarak dergi ve okurların okuma pratiği ile bir içerik türü olarak dergi ve okurların okuma pratiği arasında analitik bir ayrım yapmıştır.

\subsubsection{Bir Medya Türü Olarak GQ Türkiye Dergisi ve Okurların Okuma Pratiği}

Okurların ortalama \% 83'ü teknolojiye, \% 82'si modaya, \% 81'i kişisel bakıma, \% 61'i ilişkilere ve \% 60'1 da otomobillere tematik olarak ilgi duymaktadır. Yine aynı şekilde, okurların \% 57'si moda, \% 55'i seyahat, \% 46'sı spor ve \% 43'ü de sağlık temasına dergi sayfalarında daha fazla yer verilmesini istemektedir. Ayrıca, okurların \% 18'i derginin yenilikçiliğine, entelektüelliğine, kalitesine, ne istediğini bilen tavrına, lüks-elit oluşuna, \% 14’ü derginin içerik zenginliğine, \% 13'ü derginin duruşuna, stiline, tarzına, yine \% 13’ü derginin asi, sıra dışı, tabuları yıkan tavrına ve \% 12'si de, derginin özgür, bağımsız yapısına odaklanmaktadır. Bütün bunların ötesinde, araştırmada, dergi okurlarının, dergiyi okuma nedenleri sorgulanmakta ve katılımcıların derinlemesine görüşmelerde verdikleri cevapların şaşırtıcı bir şekilde tutarlı olduğu ve cevapların genel olarak benzer olduğu görülmektedir:

Kendi tarzını oluşturması, kendi kurallarını koyması. 25-34 Bekar - Adana

...burada amaç bilmediğimiz şeyleri de bize öğretiyor olması, gösteriyor olmasıdır... 15-19 Bekar -İstanbul

Zaten erkeklerin içinde bunlar var sadece dışarı çıkarmak lazım, o yüzden erkekler GQ okuyor. 20-24 Bekar -İstanbul

Alıntılarda da görüldüğü gibi, tarz, kural, öğrenme ve gösterme gibi kavramlar yinelenen kavramlardır ve erkek dergileri bu kavramlarla ilişkilendirilmektedir. Daha önceki alıntılarda da görüldüğü gibi, okurların ortak paydada buluştukları nokta, değişmeyen okuma alışkanlıklarıdır. Okuma pratiğine ilişkin ortak tanımlamalar, GQ Türkiye dergisinin bir yaşam biçimini temsil ettiği ve derginin kendi doğruları ile yaşayan insanların dergisi olduğu yönündedir:

GQ'nun bir dergiden fazlası, bir yaşam tarzı olduğunu çağrıştıran iyi bir motto bence. Kendi doğrularını ortaya koyan ve çevresine kulak asmayan insanların dergisi çağrışımı yapıyor. 25-34 Evli - İzmir

Bu noktada, iki farklı okuma pratiği ortaya çıkmaktadır. Birinci okuma pratiği, "tarz", "kural”, "öğrenme” ve "gösterme" gibi kavramlar aracılığıyla derginin öğretici ya da eğitici rolünü tanımlamaktadır. İkinci okuma pratiği ise, kendi doğruları ile yaşayan insanlara yapılan vurgu nedeniyle hem derginin tarzını hem de okurların tarzını birleştiren, bir başka ifadeyle, bu iki tarz arasındaki benzerliği ön plana çıkaran bir okuma pratiğidir. Aslında, bu okuma pratiklerinde, okur, bu derginin "tarzını" ve "kurallarını" benimsemekte ve dolayısıyla, bu dergide üretilen anlamların meşruluğunu her düzeyde kabullenmektedir. Ayrıca, katılımcıların bazıları, okuma pratiğinin, okurların, kendilerine güven duymalarına ve doğru tercihler yapmalarına neden olduğunu; bazı katılımcılar da, okuma pratiğinin, okurlara, 
olmaları gereken kişiyi hatırlattı̆̆ını ifade etmektedir. Bu iki durum, bir medya türü olarak derginin cazibesinin bir parçası olarak görülmektedir:

Kendine güveni olan, çoğunlukla doğru tercihler yapan. 25-34 Ankara - Evli

Olmam gereken beni hatırlıyorum. 20-24 Bekar - Bursa

\subsubsection{Bir İçerik Türü Olarak GQ Türkiye Dergisi ve Okurların Okuma Pratiği}

Alıntılarda da görüldüğü gibi, pek çok katılımcı için derginin metin yapısı önemlidir. Benzer bir değerlendirme yapan Hermes $(1995,34)$ de, kadın dergilerinin “içeriklerinden daha çok uyum sağlamak için okunduklarını” öne sürmektedir. Ayrıca, bu araştırmanın bulguları da, uyum sağlamanın önemli olduğu fikrini desteklemekte ve içerik ile anlamın çok daha fazla önemli olduğunu ortaya koymaktadır:

GQ Türkiye erkeğin manifestosudur. 25-34 Bekar - İstanbul

Aslında, bu noktada, katılımcı, belirli dergi metinleri hakkında değil, dergi okuma eylemi hakkında konuşmaktadır. Ancak, katılımcının dergi içeriğine ilişkin değerlendirmesi, okuma eyleminin, beklenen bir haz sağlayıp sağlamayacağını ya da bir başka hayal kırklığına neden olup olmayacağını da belirlemektedir. Ankette, katılımcılardan GQ Türkiye dergisini tercih etme nedenlerini belirtmeleri istenmiştir. Farklı katılımcıların, dergiyi seçerken başvurdukları kriterler (genel olarak fayda-özel hissetme ve kalite) oldukça tutarlıdır:

Türkiye'de yıllardır erkeklerin beklediği “özel hissetme” duygusunu bizlere hediye etti. GQ Türkiye özelsiniz hissi veriyor. 20-24 Bekar - Samsun

Bence GQ Türkiye, Türkiye'deki en iyi erkek dergisi. 15-19 Bekar - İzmir

Fayda ve kalite, başarılı bir dergi gazeteciliğinin anahtar kriterleridir. Bazı katılımcılar, "yaşam biçimi önerdiği”" için GQ Türkiye dergisini okuduklarını belirtseler de; katılımcılar, "faydalı", "kaliteli” ve özel hissettirdiği için GQ Türkiye dergisini okumak istediklerini öne sürmektedir. Katılımcılardan dergi söz konusu olduğunda, hoşlanıp hoşlanmadıkları şeyleri ifade etmeleri istenmiştir. Katılımcılar arasında, dergiyi beğenmediklerini ya da uygun bulmadıklarını (\% 10) ve aynı zamanda, kibirli, iddialı ve maço insanların yaşam biçimini meşrulaştıran (\% 7) dergi gazeteciliğinden hoşlanmadıklarını belirtenler de bulunmaktadır.

Bu bağlamda, dergi gazeteciliğinin faydalılığı ve kaliteli oluşu üzerinde durulmasının nedenlerini yorumlamak için birkaç olası yol bulunmaktadır. Birinci seçenek, katılımcıların, dergilere harcadıkları zamanı ve parayı haklı çıkarma ihtiyacı hissetmeleridir. Bir diğer seçenek, derginin, yaşam biçimlerine ilişkin tavsiyelerine değer verilmesidir. Çünkü bu tavsiyeler, "ideal bir ben"in fantezilerini ve gündelik yaşamda ortaya çıkan herhangi bir durumun üstesinden gelebilen pratik bir kişiyi beslemelidir (Hermes, 1995, 39). Derinlemesine görüşmeler bu konuyu daha kapsamlı açıklamak için bir firsat sunmuştur ve genel olarak, ankette verilmiş cevapları güçlendirmiştir:

Diğer dergiler arasında, modern, çalışan erkeğin edinebileceği en faydalı rehber. Günümüz erkeği GQ Türkiye'den esinlenerek tarzını, zevklerini, hobilerini ve çevresini geliştirebilir, tarzını ifade edebilir. 25-34 Evli - İstanbul

Hayata yön veren, sofistike, kaliteli, faydalı, elegan, şık, samimi, net. 25-34 Evli - Ankara

İyi bir erkek dergisi, fazlası değil. 25-34 Bekar - İstanbul/Kaliteli yaşam rehberi. Evli -Antalya

Görüşme yapılan katılımcılar, okurlar için "modern erkek" ya da "çalışan erkek", dergi için de, "hayata yön veren”, "sofistike", "kaliteli”, “faydalı", “elegan”, "şık", "samimi”, "net” ve "faydalı rehber” gibi pozitif terimleri kullanmayı sürdürmüştür. Katılımcılar, derginin sunduğu enformasyonu nasıl kullandıklarının etkili ve belirli örneklerini ortaya koymuştur. Katılımcılar, erkek dergilerinin sık sık "önemsiz", "saçma", "değersiz" ve "yüzeysel” olduğu için eleştirildiklerinin farkındadır; ancak, onlar araştırmaya konu olan derginin, "özel hissetme duygusunu hediye ettiğini”" ya da "kaliteli bir yaşam rehberi olduğunu" iddia ederek bu nosyona karşı çıkmaktadır. Katılımcılar, dergiyi, fantezilerin ya da hayallerin kaynağı olarak yorumlamamaktadır.

\subsection{Dergi Metinlerinin Özellikleri}

Derinlemesine görüşmeler, 31 Temmuz-4 Eylül 2013 tarihleri arasında gerçekleştirilmiştir. Bu nedenle, yalnızca, GQ Türkiye dergisinin Ağustos sayısında yer alan metinler çözümlenmiştir. Bu araştırmada, niceliksel içerik çözümlemesi 
yöntemi kullanılmadığı gibi, seçilmiş metinler de ayrıntılı bir şekilde çözümlenmemiştir. Bunun yerine, yinelenen metin yapılarının nasıl farklı bir okuma pratiğine ya da pratiklerine neden olabildiğini ya da olabileceğini ve yinelenen metin temalarının, okurların derin düşünebilmeleri için onlara nasıl amaca uygun enformasyon ya da olanaklar sağladığını ya da sağlayabileceğini anlayabilmek için niteliksel içerik çözümlemesi yapılmıştır. Ayrıca, çalışmada, araştırmacı, yinelenen metin yapıları ile yinelenen metin temaları arasında analitik bir ayrım yapmıştır.

\subsubsection{GQ Türkiye Dergisinde Yinelenen Metin Yapılart}

$\mathrm{Bu}$ çözümlemede, farklı okuma pratiklerini açıklamaya yardımcı olabilen ve bu okuma pratikleri ile uyumlu olan üç farklı metin yapısı ve bu yapılara ilişkin üç farklı unsur tanımlanmıştır. Birinci metin yapısı, gereksiz tekrarlar içeren metin yapısıdır. Araştırmanın örnekleminde yer alan dergi, değişmeyen bölümlere, birtakım düzenli sütunlara ve sık kullanılan başlıklara ya da alt başlıklara sahiptir. Bu nedenle, her unsurun, yinelenen bir yapının parçası olduğu görülmektedir. Derginin mizanpajı, her sayfanın köşesinde, bir kutu içinde bir manşete ya da başlığa sahiptir. Bu durum, yinelenen bir yapı içinde her sayfada tekrarlanmaktadır. Metin yapısı değişmez ve fark edilebilir olduğu için düzenli olarak dergiyi okuyan okurlar, karşılaşacakları metinleri tam olarak kestirebilmektedir. Dergiyi sürekli okuyan okurlar, her seferinde hemen hemen aynı hazzı aldıkları için okudukları dergiye güvenebilmektedir. Okurlar her seferinde biçim olarak fark edilebilen ve içeriği tazelenen favori sütunları göreceklerini bilmektedir. Bu sütunlar, derginin bir parçası haline gelmiştir. Mizanpaj değişse de içerik değişmemektedir (Örneğin, Fotoğraf 1'de görülen ve her sayıda farklı bir otomobil markasının tanıtımında olduğu gibi).
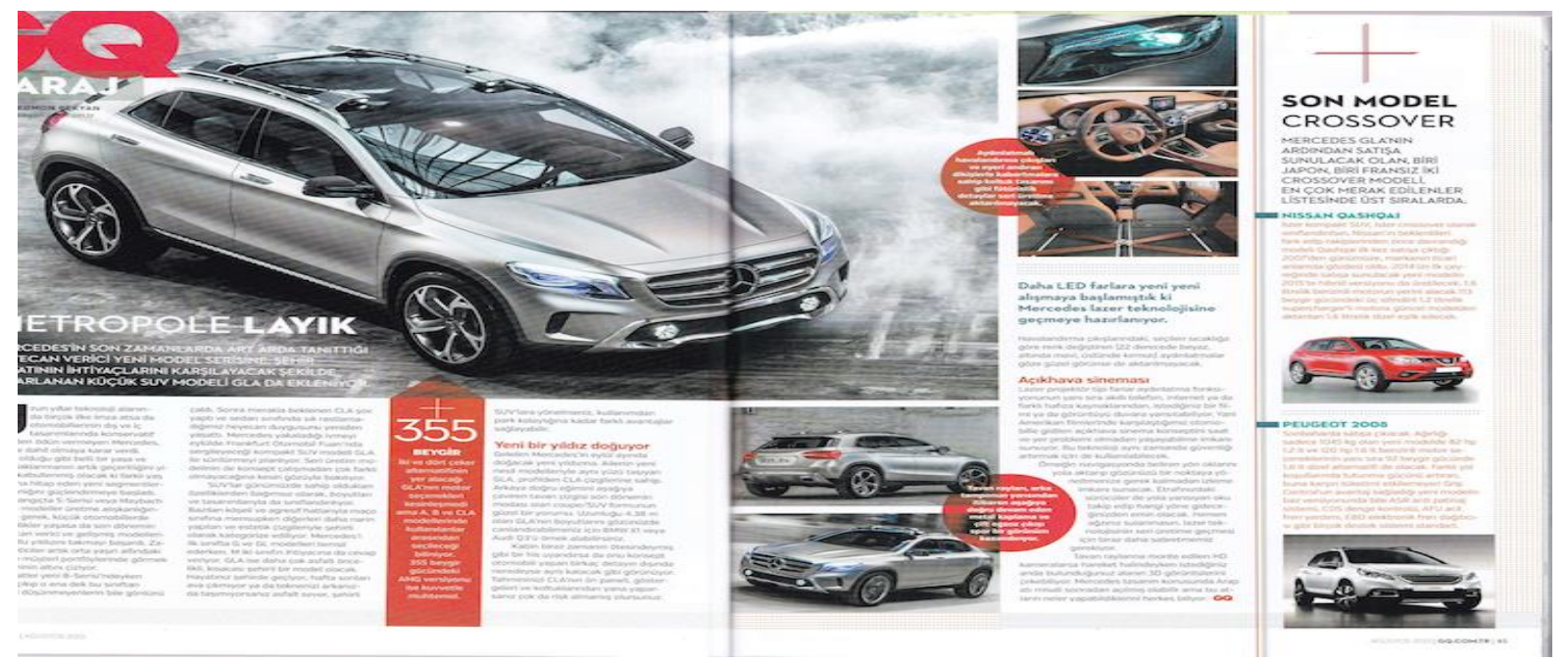

Fotoğraf 1. GQ Türkiye Ağustos 2013: 44-45

İkinci metin yapısı, her zaman dergi metnine çok sayıda girişin ve çıkışın yaşanmasıdır. Bu bir medya türü olarak dergilerin belirgin bir özelliğidir. Dergileri okumak nadiren belirli bir düzende mümkün olmaktadır. Aslında, "dergi”" sözcüğü, büyük bir mağazanın ya da deponun işlevine gönderme yapmaktadır. Çünkü dergiler, çeşitli unsurları içermektedir (aktaran Ytre-Arne, 2011a, 223). Ayrıca, bazı dergiler, görece uzun çizgisel metinler serisinden oluşabilmektedir. Metinler (yazılar), genel olarak, kutu, bölüm başlığı, alıntı, kenar çubuğu ve fotoğraf ya da resim gibi unsurlar kullanılarak çok sayıda birime ayrılabilmektedir. Örneğin, otomobile (GQ Türkiye Ağustos 2013, 44-45), modaya (GQ Türkiye Ağustos 2013, 70-71/72-73) ya da spora (GQ Türkiye Ağustos 2013, 132-133/134-135) ayrilan daha geniş tematik bölümler her zaman çok sayıda sayfaya paylaştırılmaktadır. Benzer bir şekilde, tavsiye sütunları ve yaşam biçimine ayrılan sayfalar sıklıkla daha küçük metinsel parçalardan oluşmaktadır. Genel olarak, erkek dergilerinin ve GQ Türkiye dergisinin metinsel yapısı, yalnızca doğrudan ilgi çeken şeyleri okuyan okurları, farklı uzunluklarda, biçimlerde ve konularda bir metinler serisi aracılığıyla dergiyi göz gezdirmeye davet etmektedir. Metinlerin tamamı doğrudan ulaşılabilir görünmekte; ancak, metinlerin hiçbiri büyük ölçüde zaman ve çaba gerektirmemektedir. Dergi metinlerine çok sayıda giriş ve çıkış olması, derginin, neden farklı koşullarda farklı okuma biçimlerine uyum sağlayarak deneyimlendiğini açıklayabilmektedir. Bu dergi metinleri, aslında, okurun, metne kolay girip çıkmasına imkan sağlamaktadır. 


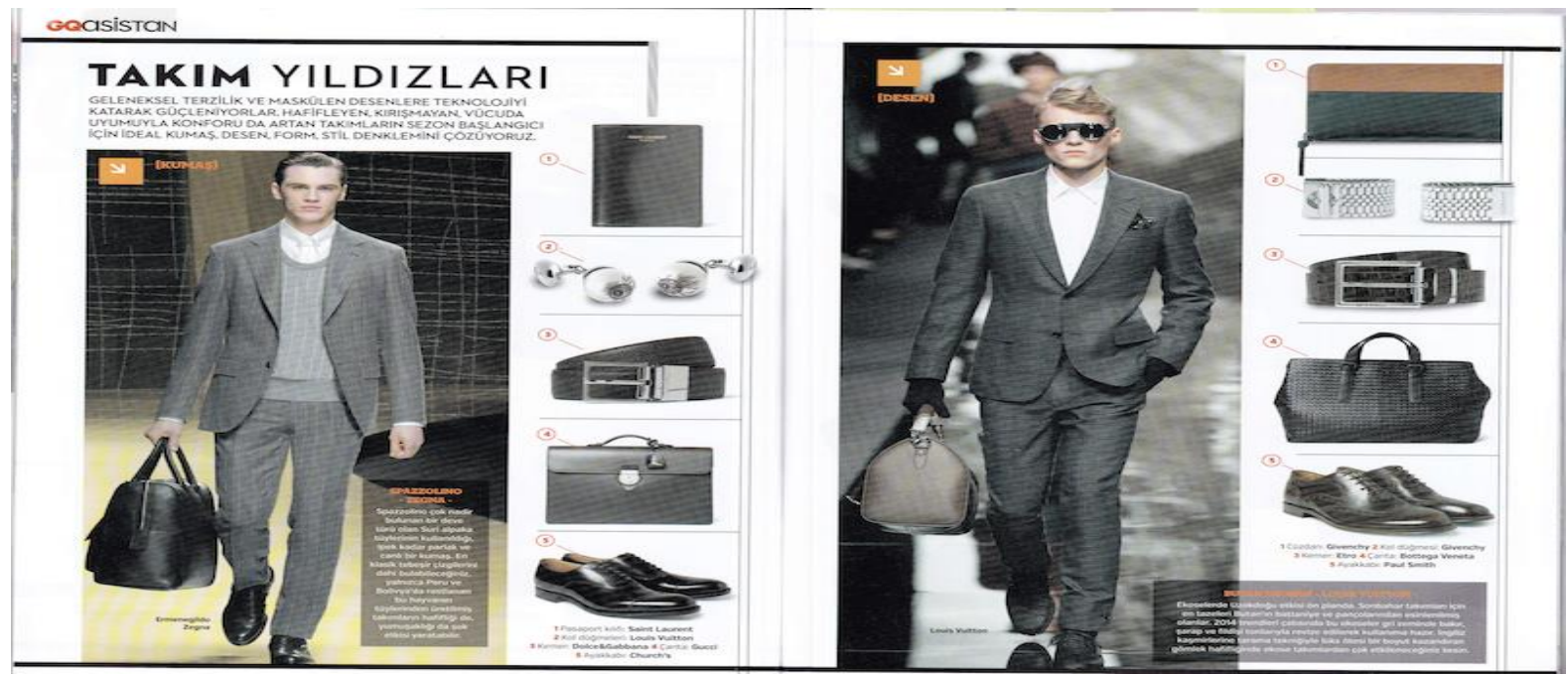

Fotoğraf 2. GQ Türkiye Ağustos 2013: 70-71

Üçüncü metin yapısı, erkek dergilerinin metin yapısına özgü farklı bir özelliktir ve bu özellik, okurların okuma yaparken sürekli olarak dört gözle beklemelerine neden olan üst-metinlerdir (Ytre-Arne, 2011a, 224). Derginin son sayfaları her zaman gelecek sayının içeriğini tanıtmaktadır. Derginin ilk sayfası ise, her zaman içindekiler tablosunu çevreleyen metin ve fotoğrafların yaptığı gibi, çok sayıda tanıtımı kapsamaktadır. Editörün sütunu düzenli olarak içeriği tanıtmakta ve yorumlamaktadır. Çok sayıda düzenli sütuna ve maddeye ek olarak, birkaç metin ise, konular arasında bağlantı kuran parçalar olarak çerçevelenmektedir. Derginin tamamını kaplayan çok sayıda görsel unsur ve gönderme, diğer içerikler hakkında ipuçları sağlamaktadır. Genel olarak, bu üst-metinler, okurların okuma yaparken sürekli olarak dört gözle beklemelerine neden olurken, öngörü ve beklentiler, okuma deneyiminin tamamlayıcı yönleri olabilmelidir. Erkek dergilerindeki ya da GQ Türkiye dergisindeki üst-metinlerin, okurların yalnızca gelecek sayfa için değil, gelecek ayın sayısı için de sürekli olarak beklenti içine girmelerine neden olan düzgün bir akış oluşturduğu söylenebilir.

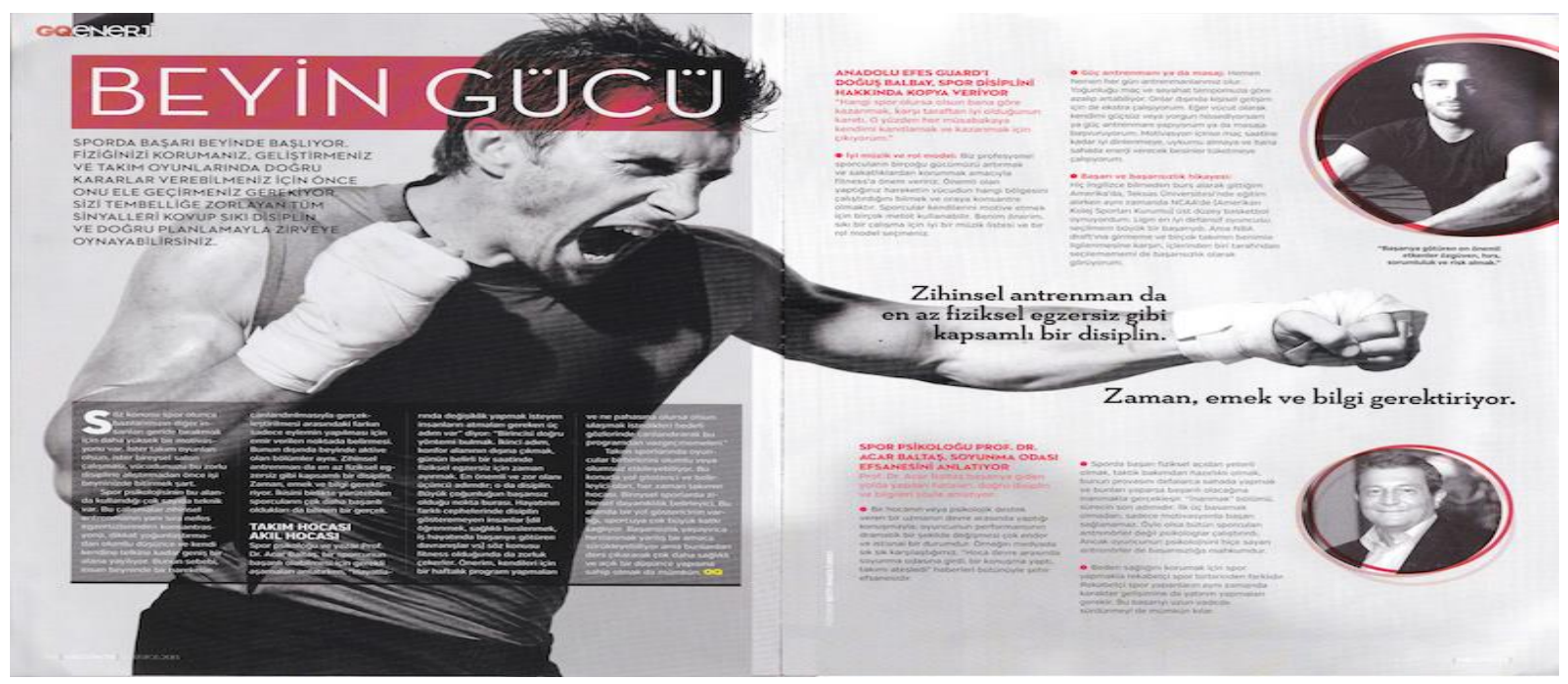

Fotoğraf 3. GQ Türkiye Ağustos 2013: 132-133

\subsubsection{GQ Türkiye Dergisinde Yinelenen Metin Temaları}

Erkek dergilerinin içeriği söz konusu olduğunda, alımlama araştırmasının gündeme getirdiği temel soru, erkek dergilerinin, çok farklı bir okur grubu tarafından anlamlı ve gerçekçi bir şekilde nasıl deneyimlenmeye başlandığıdır. Daha önce de bahsedildiği gibi, bu araştırmaya katılan katılımcılar farklı şehirlerde yaşamakta ve yaşları 15 ile 54 arasında değişmektedir. GQ Türkiye dergisi, tüm katılımcılar tarafından favori ve ideal bir dergi olarak deneyimlenmemektedir. Ancak, tüm katılımcılar dergiye abone olmayı tercih etmektedir. GQ Türkiye dergisi, böyle geniş bir ilgiyi nasıl çekmektedir? Nitel içerik çözümlemesi ile yukarıda sunulan metin yapılarının çözümlemesinde olduğu gibi, temel amaç, dergide yinelenen önemli temaları tanımlamak ve bu temaların, okurların, dergiye gösterdikleri ilgi ile nasıl uyumlu olduğunu anlamaktır. 


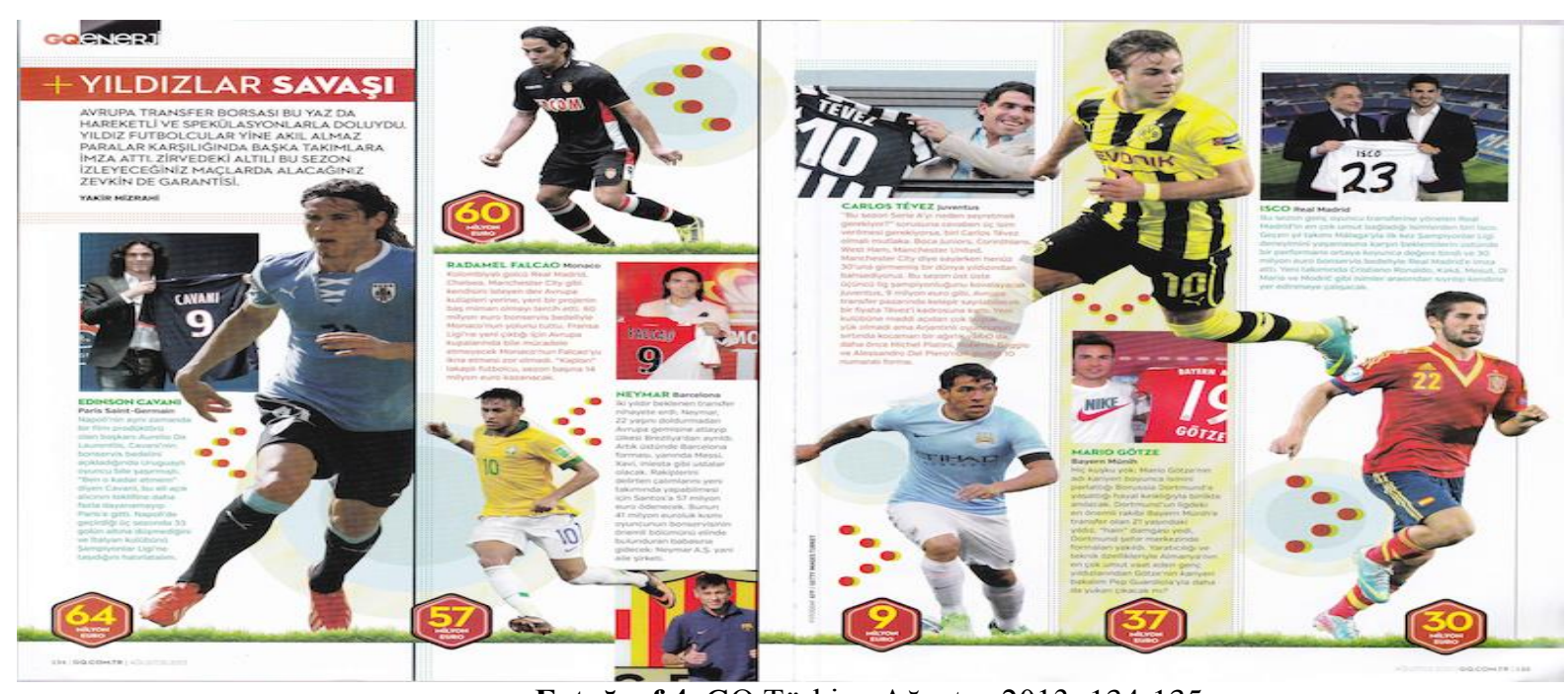

Fotoğraf 4. GQ Türkiye Ağustos 2013: 134-135

Dergideki materyalin büyük bir kısmı, birinci sıradaki ana tema ile ilişkilidir. Bu tema, "lüks yaşam biçimi" temasıdır. Şöhretlerle gerçekleştirilen betimleyici mülakatlar, şöhretlerin hem profesyonel hem de özel yaşamına odaklanma eğilimindedir. Erkek-yaşam biçimi dergileri, okurların, gündelik yaşamın karmaşasından kurtulabilmek için dergilerin kendilerine önerilerde bulunmasını istediklerini varsaymaktadır. Örneğin, moda ile ilgili bazı metinler, okurların, çok fazla zaman, enerji ve para harcayabileceği varsayımına dayanmaktadır. Birkaç yaşam biçimi alanı, pahalı modayı ya da lüks yaşamı tasvir eden çok sayıda fotoğrafla açılmaktadır. Bu nedenle, dergi, kendini bir fantezi, ilham kaynağı ve aynı zamanda, erkeklerin gündelik yaşamına temas eden bir pratik rehber olarak konumlandirmaktadır.

$\mathrm{Bu}$ araştırmadaki katılımcıların beklentileri, kendilerine rehberlik edilmesi yönündedir ve dergi metinleri, söz konusu derginin, erkeklerin gündelik yaşamına dokunabilen bir dergi olarak konumlanmasına neden olmaktadır. Dergiyi beğenmediğini ya da uygun bulmadığını ve aynı zamanda, kibirli, iddialı ve maço insanların yaşam biçimini meşrulaştıran dergi gazeteciliğinden hoşlanmadıklarını belirten katılımcılar, derginin, böyle bağlantılar kurabilme noktasında başarısız olduğunu düşünmektedir. Ayrıca, dergi, gerçekçi olmadığı ya da gerçekliğe dokunmadığı gerekçesiyle eleştirilmektedir.

\section{Sonuç ve Tartışma}

GQ Türkiye örneğinde, derginin metinsel özelliklerini ve okurların alımlamalarını çözümleyen bu çalışma, metinsel özellikler ve dergi okuma pratiği arasında anlamlı bir ilişki kurulabileceğini ortaya koymuştur. Bu çalışmanın temel unsuru, alımlama çözümlemesidir. Bu çözümleme için gerçekleştirilen anket çalışması ile özellikle derinlemesine görüşmeler, okurların deneyimlerine ve yorumlarına ilişkin zengin ve ilginç bulgular sağlamıştır: Okurların, tematik olarak ilgi duydukları ve dergi sayfalarında daha fazla yer verilmesini istedikleri konular belirlenmiştir. Okurların, dergiyi okuma nedenleri sorgulanmış ve katılımcıların derinlemesine görüşmelerde verdikleri cevapların şaşırtıcı bir şekilde tutarlı olduğu ve aynı zamanda, cevapların genel olarak benzer olduğu görülmüştür. Katılımcıların dergiyi okuma pratiğini, temelde fayda ve kalite gibi kavramlarla açıklayabilmek mümkündür. Okurlar, özellikle dergi okuma pratiği söz konusu olduğunda, bir medya türü olarak dergi ile okuma pratiğinin nedenleri arasındaki uyumu vurgularken, dergi okumayı, bir faydalanma biçimi olarak değerlendirmiş, dergi okuyarak kendilerini özel hissettiklerini ve dergi okumayı bu nedenle tercih ettiklerini ifade etmiştir. Katılımcılar hem okurlar hem de dergi için pozitif terimleri kullanmış ve araştırmaya konu olan derginin, "özel hissetme duygusunu hediye ettiğini” ya da "kaliteli bir yaşam rehberi olduğunu” iddia ederek, erkek dergilerinin “önemsiz”, “saçma”, "değersiz" ve "yüzeysel” ürünler olduğu iddiasına karşı çıkmıştır. Ayrıca, bu çalışmada, GQ Türkiye dergisinin metinsel özellikleri ile katılımcıların okuma pratiği arasındaki benzerlikleri ya da uyumu tam olarak anlayabilmek için niteliksel içerik çözümlemesine ihtiyaç duyulmuştur. Bu bağlamda, okurların, dergiye ilişkin tanımlamalarının ve alımlamalarının ne anlama gelebileceğini daha sistematik bir şekilde ve derinlemesine açıklayabilmek için niteliksel içerik çözümlemesi yöntemi uygulanmış ve okur-odaklı metin çözümlemesi yapılmıştır. Bu çözümlemede, okurların okuma pratikleri ile uyumlu olan üç farklı metin yapısı ve bu yapılara ilişkin üç farklı unsur (gereksiz tekrarlar içeren metin yapısı, dergi metnine çok sayıda girişin ve çıkışın yaşanması ve okurların okuma yaparken sürekli olarak dört gözle beklemelerine neden olan üstmetinler) tanımlanmıştır. Ayrıca, GQ Türkiye dergisinin, tüm katılımcılar tarafından favori ve ideal bir dergi olarak deneyimlenmediği ve dergideki materyalin büyük bir kısmının, "lüks yaşam biçimi”" teması ile ilişkili olduğu ortaya konulmuştur. 
$\mathrm{Bu}$ çalışmanın asıl amacı, katılımcıların yorumlarını sorgulamak değil, aksine, bu yorumların, araştırmacı tarafından anlamlandırılması olmuştur. Bu nedenle, araştırma süreci, önce ankete verilen cevapların ve derinlemesine görüşmelerin not dökümlerinin çözümlenmesi ile başlamış, daha sonra, dergi metinlerinin çözümlenmesi için bir başlangıç noktası olarak alımlama çözümlemesinin sonuçları kullanılmıştır. Araştırmacının, alımlama çözümlemesi ile okur-odaklı metin çözümlemesini birleştiren bir metodolojik yaklaşımı benimsemiş olmasının en önemli nedeni, çözümleme nesneleri olarak medya deneyimlerinin karmaşı bir doğaya sahip olabileceğine dair bir ön kabuldür. İzlerkitlenin medya deneyimleri, basit ve kolay anlaşılır değildir. Hem katılımcıların medya deneyimlerini ifade etmeleri hem de araştırmacının, katılımcılar tarafından medya deneyimlerine yüklenen anlamları kavraması zordur. Ayrıca, bu çalışmada, yalnızca, GQ Türkiye dergisinin metinsel özelliklerinin ve okurların alımlamalarının çözümlenmesi neticesinde elde edilen bulgular ile bütün (farklı kategorilerde yer alan) erkek dergilerine dair bir genelleme yapabilmek mümkün değildir.

\section{EKLER}

\section{Ek 1: Türkiye’de Erkek Dergilerine İlişkin Alımlama Araştırmalarında Gündeme Gelebilecek Beş Temel Sorun}

(1) Dergi Yöneticilerine Erişim Sorunu: Dergi yöneticilerine (genel yayın yönetmenlerine), mensubu oldukları medya gruplarının web sayfalarında belirtilen e-mail adresleri ya da telefon numaraları aracılığıyla erişebilmenin mümkün olduğu düşünülmektedir. Ancak, bazen dergi yöneticilerine, kişisel e-mail adresleri ya da telefon numaraları ya da medya gruplarının e-mail adresleri ya da telefon numaraları aracılığıyla erişebilmek mümkün olmamakta, bazen de bazı dergi yöneticileri, farklı gerekçelerle görüşme taleplerini kabul etmemektedir. Dolayısıyla, dergi yöneticilerine erişme imkanı bulamayan araştırmacının ya da araştırmacıların, dergi okurlarının iletişim bilgilerine sahip olabilmesi ve onlarla anket ya da derinlemesine görüşme yapabilmesi mümkün olamamaktadır. Bu noktada, araştırmacı ya da araştırmacılar, dergi okurlarına internet üzerinden erişebilmeyi mümkün hale getirecek başka enstrümanları kullanabilme şansına sahiptir. Örneğin, araştırmacı ya da araştırmacılar, dergi okurlarına, dergilerin Facebook ya da Twitter adresleri üzerinden ulaşabilme imkanına sahiptir, ancak, bu durum, bir takım yöntembilimsel sorunlara neden olabilmektedir.

(2) Dergi Okurlarına Erişim Sorunu: Dergi okurlarının iletişim bilgilerine, dergilerin yayıncısı olan medya gruplarının yardımıyla erişebilmek mümkündür. Ancak, bu noktada karar alma yetkisi tamamen medya gruplarına ve yöneticilerine aittir. Ayrıca, dergi okurlarına, onların iletişim bilgilerine sahip olmadan, dergilerin Facebook ya da Twitter adresleri aracılığıla erişebilmek ve onlarla anket ya da derinlemesine görüşme yapabilmek de mümkündür. Ancak, medya gruplarının ve yöneticilerinin izni olmadan anket ya da derinlemesine görüşme yapma girişiminde bulunmak hem yasal hem de etik değildir. Ayrıca, söz konusu seçenek, daha önce de belirtildiği gibi, bir takım yöntembilimsel sorunlara neden olabilmektedir. Bu nedenle, mutlaka medya grupları ve yöneticileri ile temas halinde olmak ve onların izniyle araştırma yapmak gerekmektedir, aksi takdirde, araştırma yapmak ya da araştırmayı tamamlamak mümkün değildir.

(3) Dergi Tirajları Hakkında Bilgi Sahibi Olamama Sorunu: Medya araştırmalarında, örneklem oluşturulurken dikkate alınan kriterlerden biri, medya türünün elde etmiş olduğu tirajdır ya da izlenme oranıdır. Dağıtım şirketlerinin dergi yayıncıları ile yapmış oldukları anlaşmalar nedeniyle, erkek dergilerinin tirajlarına hem söz konusu dergilerin yöneticileri aracılığıyla hem de internet üzerinde gerçekleştirilen aramalar neticesinde ulaşabilmek mümkün olamamaktadır. Bu noktada, bu tür çalışmalarda, örnekleme dahil edilecek dergilerin seçilmesinde belirleyici olan asıl kriter, tiraj değildir. Asıl kriter, dergilerin içeriği, hedef okur kitle ve dergilerin üretim biçimidir.

(4) Dergiler Arasında Tipolojik Olarak Tercih Yapma Sorunu ya da İkilemi: Erkek dergileri, genel olarak pornografik (aşırı müstehcen olmayan) dergiler ve yaşam biçimi dergileri olmak üzere iki ana kategoriye ayrılmaktadır. Ancak, erkek dergilerini, pornografik dergilere ve yaşam biçimi dergilerine alternatif olarak, genç erkek ya da delikanlı dergileri, stil-moda dergileri, spor dergileri ve sağlık dergileri olmak üzere dört ana grupta toplayabilmek de mümkündür (Erdoğan, 2014, 19-21). Ayrıca, erkek dergileri, içerik olarak bu kategorilerin her birine özgü özelliklere de sahip olabilmektedir. Daha da önemlisi, küresel medya grupları tarafindan yayımlanan, uluslararası erkek dergileri pazarında satışa sunulan ve söz konusu tipolojide yer alan erkek dergilerinin bazıları Türkiye'de yayımlanmamaktadır. Dolayısıyla, dergiler arasında tipolojik olarak tercih yapabilmek zorlaşmakta ya da mümkün olamayabilmekte ve tüm erkek dergilerine ilişkin bir genelleme yapabilmek imkansız hale gelmektedir. Bu nedenle, Türkiye'de yayımlanan ve aynı kategoride yer alan dergilerin okurları ile bir alımlama çözümlemesi yapmak daha mantıklıdır. Bir başka seçenek ise, Türkiye'de yayımlanan ve farklı kategorilerde yer alan dergilerin okurları ile bir alımlama çözümlemesi yapmak ve elde edilen bulgular ile dergileri karşılaştırmaktır.

(5) Küresel ve Yerli Medya Grupları Arasında Tercih Yapma Sorunu ya da İkilemi: Küresel medya grupları tarafından yayımlanan ve uluslararası erkek dergileri pazarında satışa sunulan dergiler, aynı içeriği eş zamanlı olarak kullanabilme ve dağıtabilme kapasitesine sahiptir. Ayrıca, bu medya grupları, kendi ürettikleri kültürel ürünleri dünya çapında pazarlamakta ve özellikle Los Angeles, New York, Paris, Londra, Münih ve Berlin gibi küresel kültür endüstrisinin 
üretim merkezlerinde üretilen medya içeriğinin ve formatlarının küresel olarak yayılmasına ve yaygınlaşmasına katkıda bulunmaktadır (Krätke, 2003, 612). Ayrıca, bu dergilerde, küresel medya hem hegemonik hem de küresel olarak kontrol ya da disiplin edilen tek bir erkeklik modelini temsil etmekte ve dolayısıyla, erkek bedeni küreselleşmekte (Connell, 2000) ve küresel medya grupları tarafından yayımlanan erkek dergilerinin şablonu, çok farklı kültürel bağlamlarda başarılı bir şekilde yeniden üretilebilmektedir. Dolayısıyla, küresel medya grupları tarafından yayımlanan ve uluslararası erkek dergileri pazarında satışa sunulan dergilerin içeriği benzeşmektedir. Bu noktada, araştırmacı ya da araştırmacılar, üç seçenekten birini tercih etmek durumundadır. Birincisi, araştırmacı ya da araştırmacılar yalnızca küresel medya grupları tarafından yayımlanan ve uluslararası erkek dergileri pazarında satışa sunulan dergilerin okurları ile bir alımlama çözümlemesi yapmalıdır. İkincisi, yalnızca yerli medya grupları tarafından yayımlanan erkek dergilerinin okurları ile bir alımlama çözümlemesi yapmalıdır. Üçüncüsü, küresel ve yerli medya grupları tarafından yayımlanan erkek dergilerini karşılaştırmalıdır. Ancak, söz konusu karşılaştırma neticesinde elde edilecek bulgular üzerinden kategorik bir genelleme yapılamayabilir ya da böyle bir olasılık söz konusudur.

\section{Ek 2: Türkiye Örneğinde Alımlama Araştırmasının Anket ve Derinlemesine Görüşme Soruları}

(1) Cinsiyetiniz nedir?

a) Erkek b) Kadın

(2) Yaşınız nedir?

a) $15-19$ b) $20-24$ c) $25-34$ d) $35-44$ e) $45-54$

(3) Hangi şehirde yaşıyorsunuz?

a) İstanbul b) Ankara c) İzmir d) Diğer büyük şehirler e) Diğer

(4) Medeni durumunuz nedir?

a) Bekar b) Evli c) Boşanmış d) Dul

(5) GQ Türkiye dergisini hangi sıklıkla okursunuz?

a) Ayda bir-her sayısını okurum b) İki-üç ayda bir c) Dört-beş ayda bir d) Yılda bir iki defa e) Daha seyrek

(6) Çocuğunuz var mı?

a) Evet b) Hayır

(7) GQ Türkiye Ağustos sayısının kapağını beğenme nedeniniz nedir?

a) Kapak kızı b) Diğer

(8) GQ Türkiye'de yer alan temalardan hangisi daha çok ilginizi çekiyor?

a) Moda b) Otomobil c) Kişisel bakım d) İlişkiler e) Teknoloji

(9) GQ Türkiye'de hangi temaları daha çok görmek istersiniz?

a) Moda b) Seyahat c) Spor d) Sağlık-beslenme e) Teknoloji f) Kişisel bakım g) İlişkiler h) Dekorasyon

1) Otomobil i) Diğer

(10) "Bildiğini okuyan erkeklerin dergisi” ifadesi sizce GQ’nun hangi yönünü öne çıkarıyor?

$\mathrm{Bu}$ ifade dergi hakkında size ne anlatıyor, neyi çağrıştırıyor?

a) İçerik zenginliği b) Duruşu-stili-tarzı olan c) Asi-sıradışı-tabuları yıkan d) Özgür-bağımsız

e) Yenilikçi-entelektüel-kaliteli-ne istediğini bilen-lüks-elit f) Beğenmiyorum-uygun bulmuyorum

g) Özgüvenli h) Farkl1-özgün 1) Kibirli-iddialı-maço

Adınız ve soyadınız (Yalnızca ilk harflerini belirtiniz):

(11) "Bildiğini okuyan erkeklerin dergisi” ifadesi sizce GQ’nun hangi yönünü öne çıkarıyor?

Bu ifade dergi hakkında size ne anlatıyor, neyi çağrıştırıyor?

(12) "Bence GQ Türkiye ..." boşluğu size en uygun gelen ifade ile tamamlayınız.

\section{KAYNAKÇA}

Alasuutari, Pertti. (1999). Introduction: Three Phases of Reception Studies, Rethinking the Media Audience: The New Agenda, Ed. Pertti Alasuutari, London: Sage.

Anstiss, David ve Lyons, Antonia. (2013). “From Men to the Media and Back Again: Help-Seeking in Popular Men's Magazines." Journal of Health Psychology, 0 (0): 1-13.

Attwood, Feona. (2005). "Tits and Ass and Porn and Fighting: Male Heterosexuality in Magazines for Men." International Journal of Cultural Studies, 8 (1): 83-100.

Aydoğan, Filiz. (2008). "Erkeklerin Tüketici Kitleler Haline Getirilmesinde Erkek Dergilerinin Rolü ve İçerik Analizi." Marmara Üniversitesi Sosyal Bilimler Enstitüsü Dergisi, 8 (29): 239-246.

Bat1, Uğur. (2007). "Postmodernism, Consumption and Fashion: The Representation of Ideal Men Throughout the Fashion in Turkish Magazine Advertisements.” İstanbul Üniversitesi İletişim Fakültesi Dergisi, 30: 19-36.

Benwell, Bethan. (2005). “-Lucky This is Anonymous- Ethnographies of Reception in Men's Magazines: A 'Textual Culture' Approach.” Discourse\&Society, 16 (2): 147-172. 
Benwell, Bethan. (2004). "Ironic Discourse: Evasive Masculinity in Men's Lifestyle Magazines." Men and Masculinities, 7 (1): 3-21.

Benwell, Bethan. (2003a). Introduction: Masculinity and Men’s Lifestyle Magazines, Masculinity and Men's Lifestyle Magazines, Ed. Bethan Benwell, Oxford-Malden: Blackwell.

Benwell, Bethan. (2003b). Ambiguous Masculinities: Heroism and Anti-Heroism in the Men's Lifestyle Magazines, Masculinity and Men's Lifestyle Magazines, Ed. Bethan Benwell, Oxford-Malden: Blackwell.

Benwell, Bethan. (2002). Is There Anything 'New' About These Lads? The Textual and Visual Construction of Masculinity in Men's Magazines, Gender Identity and Discourse Analysis: Discourse Approaches to Politics, Society and Culture, Eds. Lia Litosseliti ve Jane Sunderland, Amsterdam, Netherlands: John Benjamins Publishing Company.

Connell, R. William. (2000). The Men and the Boys, Berkeley-Los Angeles: University of California Press.

Currie, Dawn H. (1999). Girl Talk: Adolescent Magazines and Their Readers, Toronto: University of Toronto Press.

Edwards, Tim. (1997). Men in the Mirror: Men's Fashion, Masculinity and Consumer Society, London: Cassell.

Erdoğan, İlker. (2014). "Erkek Dergilerini Okumak: Dergilerin İçeriği, İdeolojisi ve Okurları Üzerine Bir Değerlendirme.” Uluslararası Kıbrıs Üniversitesi Folklor/Edebiyat Dergisi, 20 (80): 9-32.

Erdoğan, İlker. (2013a). “Erkek Dergilerinde Sağlıklı Erkek Neden İdeal Erkektir? Men's Health Dergisinde Hegemonik Erkeklik ve Popüler Sağlık Söylemi.” Galatasaray Üniversitesi İletişim Fakültesi Dergisi İleti-ş-im (Sağlık İletişimi Özel Sayısı), 3: 133-154.

Erdoğan, İlker. (2013b). “Erkek Dergilerinde (Men’s Health-FHM-Esquire-GQ Türkiye Örneğinde) İdeal(leştirilen) Erkek(lik) İmajının İçerik Çözümlemesi.” Akdeniz Üniversitesi İletişim Fakültesi Dergisi, 20: 164-188.

Erdoğan, İlker. (2011). Erkek Dergilerinde (Men's Health-FHM-Esquire Türkiye Örneğinde) Hegemonik Erkek(lik), Beden Politikaları ve Yeni Erkek İmajı, Medyada Hegemonik Erkek(lik) ve Temsil, Ed. İlker Erdoğan, İstanbul: Kalkedon Yayınları.

Frazer, Elizabeth. (1987). "Teenage Girls Reading Jackie.” Media, Culture and Society, 9 (4): 407-425.

Gauntlett, David. (2008). Media, Gender and Identity: An Introduction, London-UK: Routledge.

Gill, Rosalind. (2003). Power and the Production of Subjects: A Genealogy of the New Man and the New Lad, Masculinity and Men's Lifestyle Magazines, Ed. Bethan Benwell, Oxford-Malden: Blackwell.

Gregorio Godeo, Eduardo de. (2006a). "Exploring Identity Issues in British Men's Magazines' Problem Pages: A Cultural Studies Perspective.” Miscelánea: A Journal of English and American Studies, 34: 41-61.

Gregorio Godeo, Eduardo de. (2006b). "Critical Discourse Analysis as an Analytical Resource for Cultural Studies: Exploring the Discursive Construction of Subject Positions in British Men's Magazines' Problem Pages." Revista Alicantina de Estudios Ingleses, 19: 83-100

Hall, Stuart. (2005). Kodlama, Kodaçımlama, Medya ve İzleyici: Bitmeyen Tartışma, Der. Şahinde Yavuz, Çev. Yiğit Yavuz, Ankara: Vadi Yayınları.

Hermes, Joke. (1995). Reading Women's Magazines: An Analysis of Everyday Media Use, Cambridge: Polity Press.

Hoijer, Brigitta. (2005). İzleyicilerin Televizyon Programlarını Alımlayışı: Kuramsal ve Metodolojik Değerlendirmeler, Medya ve İzleyici: Bitmeyen Tartışma, Der. ve Çev. Şahinde Yavuz, Ankara: Vadi Yayınları.

Hollow, Matthew. (2012). "Perfect Lives: Lifestyle Magazines and Utopian Impulses in Contemporary British Society." International Journal of Cultural Studies, 15 (1): 17-30.

İrvan, Süleyman. (1994-1995). Eleştirel Yaklaşımlarda İzleyici Araştırmaları: Bir Yöntem Olarak Alımlama Çözümlemesi, İLEF Yıllık 94, Ankara: Ankara Üniversitesi İletişim Fakültesi Yayınları.

Jackson, Peter vd. (2001). Making Sense of Men's Magazines, Oxford-Malden: Polity.

Jackson, Peter vd. (1999). “Making Sense of Men's Lifestyle Magazines.” Environment and Planning: Society and Space, 17 (3): 353-368.

Jensen, K. Bruhn. (2005). Sosyal Kaynak Olarak Haberler: Danimarka Televizyon Haberleri Hakkında Nitel Ampirik Bir Çalışma, Medya ve İzleyici: Bitmeyen Tartışma, Der. ve Çev. Şahinde Yavuz, Ankara: Vadi Yayınları.

Jensen, K. Bruhn ve Rosengren, K. Erik. (2005). İzleyicinin Peşindeki Beş Gelenek, Medya ve İzleyici: Bitmeyen Tartışma, Der. Şahinde Yavuz, Çev. Şahinde Yavuz ve Yiğit Yavuz, Ankara: Vadi Yayınları.

Kula Demir, Nesrin. (2009). Erkek Dergilerindeki Reklam Fotoğraflarında (Yeniden) Üretilen Metroseksüel Kimlik, Erkek Kimliğinin Değişe(meye)n Halleri, Ed. Huriye Kuruoğlu, İstanbul: Beta Yayınları.

Krätke, Stefan. (2003). "Global Media Cities in a World-wide Urban Network." European Planning Studies, 11 (6): 605-628.

Malkin, Amy R. vd. (1999). “Women and Weight: Gendered Messages on Magazine Covers.” Sex Roles, 40 (7-8): 647656.

Morley, David. (2005). Etkin İzleyici Kuramı: Sarkaçlar ve Tuzaklar, Medya ve İzleyici: Bitmeyen Tartışma, Der. Şahinde Yavuz, Çev. Yiğit Yavuz, Ankara: Vadi Yayınları.

Mutlu, Erol. (2005). Globalleşme, Popüler Kültür ve Medya, Ankara: Ütopya Yayınevi.

Osgerby, Bill. (2001). Playboys in Paradise: Masculinity, Youth and Leisure-Style in Modern America, Oxford-New York: Berg. 
Rogers, Anna. (2005). “Chaos to Control: Men’s Magazines and the Mastering of Intimacy.” Men and Masculinities, 8 (2): 175-194.

Schirato, Tony ve Yell, Susan. (1999). "The 'New' Men’s Magazines and the Performance of Masculinity." Media International Australia incorporating Culture and Policy, 92: 81-90.

Spalding, Roy vd. (2010). "Relationship Advice in Top-Selling Men’s Magazines: A Qualitative Document Analysis." Journal of Feminist Family Therapy, 22 (3): 203-224.

Stevenson, Nick vd. (2003). Reading Men's Lifestyle Magazines: Cultural Power and the Information Society, Masculinity and Men's Lifestyle Magazines, Ed. Bethan Benwell, Oxford-Malden: Blackwell.

Stevenson, Nick. (2002). Understanding Media Cultures: Social Theory and Mass Communication, London: Sage.

Stevenson, Nick vd. (2000). "The Politics of New Men's Lifestyle Magazines.” European Journal of Cultural Studies, 3 (3): 366-385.

Stibbe, Arran. (2004). "Health and the Social Construction of Masculinity in Men's Health Magazine." Men and Masculinities, 7 (1): 31-51.

Vigorito, Anthony J. ve Curry, Timothy J. (1998). "Marketing Masculinity: Gender Identity and Popular Magazines." Sex Roles, 39: 135-152.

Ytre-Arne, Brita. (2011a). "Women's Magazines and Their Readers: The Relationship between Textual Features and Practices of Reading." European Journal of Cultural Studies, 14 (2): 213-228.

Ytre-Arne, Brita. (2011b). "Women's Magazines and the Public Sphere.” European Journal of Communication, 26 (3): 247-261.

Ytre-Arne, Brita. (2011c). "I Want to Hold It in My Hands: Readers' Experiences of the Phenomenological Differences between Women's Magazines Online and in Print." Media, Culture\&Society, 33 (3): 467-477. 